\title{
The Influence of Computer-Mediated Communication on Students' Writing Ability
}

\author{
Hadriana Hadriana \\ English Department, Faculty of Teacher Training and Education \\ Universitas Riau, Kampus Panam Pekanbaru, Riau, Indonesia \\ ad1208@yahoo.co.id
}

\begin{abstract}
There are many ways of teaching writing that can be applied by lecturers to improve the students writing' ability. Some of them try to improve the students' writing ability by improving sub-skills of writing: sentence building, developing ideas, organizing ideas, and etc., while others try to use various kinds of learning tools during their teaching and learning process. However, the use of computer and internet cannot be ignored in this modern era. This study aimed to show whether there is a significant influence of Computer-Mediated Communication (CMC) application on students' writing ability and to know about the students' perceptions on CMC application in Writing classes. One group pretest-posttest experimental design was conducted at English Study Program, Faculty of Teachers Training and Education-Riau University on odd semester of academic year 2015-2016. Cluster random sampling technique was used to select one class of students to become the sample. These students, then, was given treatment by applying CMC in teaching Writing. The instrument used were a writing test and a questionnaire. The obtained data analyzed by using SPSS version 21 for Windows. The results of the data analysis illustrates that there is significant influence of CMC application on the students' writing ability. Students' perceptions on CMC application in the learning activities was also good.
\end{abstract}

Keywords: CMC; Writing ability; Experimental design; Writing test; Questionnaire

\section{Introduction}

Writing is one of the compulsory subjects for all students of English Study Program of FKIP - Riau University. This course aims to develop students' ability in order to be able to communicate in written form. Before finishing their study, in other words, before they obtain their "Sarjana" degree, the students are given three levels of Writing Classes, namely: Writing I, Writing II, and Writing III. After completing Writing III, the students are expected to have the ability to write various forms of writing: personal writing, transactional writing, and academic writing [1].

For a university student, having the ability to write is not only an option - it is a necessity. As Santangelo \& Olighouse in [2] argue that together with reading ability, writing ability is a predictor of academic success and an important requirement for participation in community life and in the global economy. However, it is still a big question whether the goals of teaching writing that have been stated can be achieved by the students of English Study Program. How is the writing ability of the students at this time? Writing ability of the students can be seen from several components: grammar, vocabulary, mechanics, fluency, and organization. Research conducted by Hadriana and Mahdum in [3] prove that the problems faced by the students in writing include all of these components.

Based on interviews conducted, it was found out that Writing is one of the subjects considered difficult by the students. It was hard for them to obtain good writing ability 
although they had tried hard. There are several reasons for this. First, in writing classes the students need to develop their ability to write in a communicative way in English that has different rhetorical structure from Indonesian. Incorrect uses of English grammar many times cause the sentences they produce are vague or unclear. Secondly, in writing classes the students do not just write sentences or paragraphs by following the rules of grammar, but they need to learn and understand how to communicate their ideas in writing so that their sentences or paragraphs can be understood easily by others. Thirdly, the students also face problems in getting the idea, choosing the right words, and develop ideas in correct sentences.

One way that can be done by the lecturers to help the students to improve their writing ability is by using Information and Communication Technology (ICT) in teaching and learning activities [4-8]. The use of ICT in the last few decades, such as the use of computers the internet in language learning is able to provide a new innovation in learning activities as well as develop students' English language skills [9]. Through the use of computers and internet the students are able to empower the use of technology and able to complete their tasks better. In writing classes, for example, the students can take advantage of using computers to check correct spelling and editing. Moreover, internet usage is also useful to add students' insight associated with the addition of vocabulary and grammatical knowledge that can eventually add proficiency in writing.

In learning activities using computers and internet, communication can be done through the mediation of a computer, or it is called Computer-Mediated Communication (CMC) [10-15]. This communication is somewhat different from the communication conducted through face-to-face communication. Berge and Collins [16] define CMC as the use of computers, systems and networks for the transfer, storage and retrieval of information among humans. By applying CMC two or more people interact with computers using tools via the application of program that is installed on the computer. The CMC involves the use of the computer as a tool, rather than as a deliverer of instructional material.

This paper is aimed to show the influence of CMC application on the students' writing ability and to determine the students' perceptions on $\mathrm{C} / \mathrm{MC}$ application in writing classes. So, the research questions to be answered in this research are: (1) Is there any significant influence of CMC application on the students' writing ability? (2) How is the students' perceptions on CMC application in Writing classes? In summary, the contributions of this research are given as follows:

a. Try to present concise and precise recent progress on CMC application in teaching and learning process, especially in writing classes.

b. Point out the challenges of using technology, especially computer and internet to arise the students' attention, curiosity, and motivation in studying.

c. Provide more knowledge and information for English teachers and lecturers about more creative and innovative way of teaching writing through the use of computers and internet.

d. Provide references for the next researchers at the same field.

The remaining structure of this paper is organized as follows: Section 2 presents literature review. Section 3 gives the description of research method and procedure. Section 4 presents result and discussions. Finally, Section 5 will give concluding remarks and future research opportunities. 


\section{Related Works}

Some reviews of several aspects related to Writing and $\mathrm{CMC}$ application will be discussed in the following parts.

\subsection{Understand the Definitions, Purposes and Kinds of Writing}

Speaking and writing both can be categorized as the way of communication. Anytime someone speaks or communicate verbally, he can use various assistances such as tone of voice, rhythm, or the speed of sound to convey his thoughts or ideas that can be understood properly and easily by the listeners. Different things happen when someone writes. He can only express his ideas through words without any interaction with the readers.

Chitravelu, et al. in [17] say that speaking skills can be acquired naturally began in the early years of life without having to follow systematic teaching and learning process. However, in order to obtain writing skill, someone needs to be taught how to write properly and systematically in class, although every day he is dealing with different types of writing, such as bills, boos, letters, newspapers, magazines, advertisements, and etc. Writing teachers, therefore, have to understand several aspects before he teaches writing, such as: the purpose of writing, types of writing, steps in writing, the characteristics of each type of writing and so on. In order to write successfully, the students have to learn stage by stage about sub-skills of writing as well as how to develop the ideas. This opinion is in accordance with the opinion of Othman and Baki in [18] who argued that to be able to produce a good and memorable writing is not easy, but should be through a complex process. Therefore, writing activities should be carried out in accordance phases systematically.

One definitions of writing is given by Massi [19]. According to her, writing is an interactive process by nature because it is developed from symbolic interactions among the writer, the text, and the reader. While according to Chitravelu, et al. [17] writing is a system for interpersonal communication using signs or graphic symbols that can be seen on a flat surface such as paper, cloth or even stone slabs. All languages have their own graphic symbols. English uses a system that consisting of 26 pieces of letters (a, b, c, ... , z). The ability to write is a complex cognitive ability and is a challenging task for the lecturers and the students when the writing class is occurred. The lecturers argue that teaching writing is a daunting task because writing activities involve mental processes and includes various types of sub-skills such as drafting, editing, revising, organizing, and so forth. Hence the task of lecturers should first make the students understand that sub-skills before teaching actual writing skills overall.

There are several reasons why people write, some of which are: to inform, to persuade, to give instructions, to express feelings and many else. Because of these different reasons, a variety of kinds of writing are produced in accordance with their respective functions. Chitravelu et al. in [17], classify the type of writing into three, namely: personal, creative and transactional writing. Personal writing usually is a form of writing that is personal, informal and do not really follow the rules of grammar. Examples of this type of writing are: personal letters, notes, diaries, messages, shopping lists, and so on. Transactional writing is a kind of writing that is well-organized, follow the rules of grammar and require more attention of the writer about the information or messages to be conveyed. That's why this type of writing is categorized into formal communication. Examples of this kind of writing are: proposals, working papers, reports, government regulations, and other official letter and so on. Creative writing is the kind of writing for self- expression or leisure. Examples of this type of writing are: poetry, short stories, anecdotes and songs.

To produce any form of writing requires a process. Many writing experts give their opinions on how the process of writing should be done so that the writing they produced becomes a memorable one. According to Leki [20] the writing process consists of: 
exploring and generating of ideas, seeking out of feedback, and the reworking and revising the presentation of reviews those ideas. According to Ur [21] writing process consists of: (1) preparation; (2) process; and (3) product. Another opinion expressed by Brown [22], which classifies English writing process into three stages: prewriting; drafting; and revising. After the writing process is finished, the assessment toward the products should be done by the lecturer. Hughes [23] suggested two ways that can be used in assessing the students' writing, namely: (1) holistic method, and (2) analytic method. In holistic method the assessment can be made based on the overall impression given by the lecturer, while the analytic method, the assessment is made based on the ratings given range scale of 1-6 for every aspect of the assessment component. Components assessed are: grammar, vocabulary, mechanics, fluency, and organization. According Chitravelu, et al. in [17], the assessment of the article can also be done in discrete feature test, where assessment is done separately on each component of the writing to be tested. For example, the assessment of punctuation, grammatical structures, vocabulary and others are done separately.

\subsection{Computer-Mediated Communication Application in Teaching and Learning Writing}

The situations of the students today are completely different from the situations of students a few decades ago, both in terms of necessity and in learning style. Nowadays, the existence of technology is an integral part of students' life, and cannot be separated from their activities, including the students of English Study Program - FKIP Riau University. Learning devices such as a computer (lap top) and internet are no longer a luxury. Almost all students have had a lap top and a variety of shapes and types of gadgets. Therefore, the use of the technology in teaching and learning of writing need to be developed. Teaching writing in a traditional way that is known as teacher-centered may be considered old-fashioned and boring by the students. They are already familiar with the various forms of texts, images, videos, hyperlinks, info graphics, and etc., as these are the main component of their digital world. Lecturers, therefore, need to ensure that these components can be included in our learning activities. This idea is in accordance with the opinion of Graham \& Perin in [24] who say that in this digital era, the use of technology in teaching writing is very important.

The use of technology in learning writing can also dispel the boredom, and at the same time develop creativity engagement. According to Peterson-Karlan \& Parette in [25], the use of technology can be used not only to improve the ability to write, but can also make the students love writing. The use of technology is also able to provide support for all stages of the writing - planning, transcribing, and revising. Moreover, the use of technology can improve the writing skills as well as understanding about mechanics, spelling, and organizing. Technology also provides a variety of new sources and ways to get information.

One example of using technology in teaching and learning process is the application of Computer-Mediated Communication (CMC). The $\mathrm{CMC}$ is the process by which people create, exchange, and perceive information using networked telecommunications systems (or non-networked computers) that facilitate encoding, transmitting, and decoding messages. According to Tomic in [26] CMC is a process of communication through computers for various purposes. Hirvela in [27] says that in the educational context, CMC plays an effective role in linking students together via the computer. As the applications of CMC are concurrently diverse, they work through which they communicate with one another electronically in or outside the classroom.

CMC is divided into synchronous and asynchronous modes [28] Synchronous communication is a communications through internet to interact at the same time. In other words, all users can communicate at the same time among others, using technologies such as chat programs, audio and video conferencing, electronic 
whiteboards, and etc. According to Lancaster, et al. [29] Synchronous communication is also known as instant messaging (IM). IM is known as a free application that allows users to exchange instant messages. This communication uses words as a message, delivers and receives instantaneously as if in conversation and together with interpersonal communication. IM in the learning process is usually used as a medium of collaboration, both among students and between lecturers and students for the purpose of knowledge sharing [30]. IM is not intended to replace the conventional education system, but more appropriate role as a complement to the learning process.

Asynchronous communication is a communication via internet where the sender and the recipient is not in the same place and time when they interacts, but the receiver will get the message. In other words, the application of communication is not depending on the time. The users can access the system and the communication between them adjusted to the time respectively. This type of communication is represented by the electronic mail (e-mail). In communication via e-mail between the sender of the message with recipient of the message will most likely not be at the place and time simultaneously. Messages sent to go through a transmission route before reaching a recipient address. Although the activities and processes of using computer and internet mediated communication is the exchange data via a computer but still involves humans as giver of context or situation on the activity and the communication process, which covering the context of individual, group, organization, and social. At the individual level, the user is using internet tools for seeking and receiving information and communicating with other users. E-mail is the most widely used facilities at this level. At levels of communications group, e-mail is still being used in the form of a list server or mailing list.

E-mail itself consists of two types, based on the desired interactions, namely e-mail person to person (point to point) which is an e-mail from one person to one other person, as well as group e-mail (point to multi-point) is an e-mail from one person to a group of person and vice versa. The second type is referred to as e-mail groups (e-groups) or mailing list. Recipient in communication via e-mail cannot receive messages sent to him when it is not in line condition. Messages sent to the recipient will be through the route and need a matter of time. Reply or feedback from the receiver of the message would occur if there is a motivation of the message recipient for sending a message back (reply). When this happens, the recipient of the message will change the role (role switching) becomes sender and the sender of the message to change the role of being the recipient. Another form of asynchronous communication is the online broadcast communication. This kind of communication can be done via the web facility. There are two types of web, namely official website (usually web that belong to legitimate institution) and the second type is an unofficial web (web that owned and managed personally). Although communicators in the web is the web master, web hosting provider or internet service provider, but the feedback remains addressed to the source in this case the relevant institutions or individuals, through e-mail facilities. Thus the feedback submitted to message source is the direct feedback that is both asynchronous communications.

For educational purposes, the use of CMC application may enhance collaborative writing and the social production of knowledge. According to Young in [31] use the CMC can create interactive, communicative, and collaborative learning environment as well as to improve writing skills through engagement, confidence and responsibility. Hussin et al. [32] also claim that the use of CMC application give a positive effect of on students' writing performance as well as improve their writing anxiety level. The CMC application may also arise the students' attitude and interest towards learning to write essays [33]. The CMC application is not only used in writing classes, but can give a positive effect on students' oral performance [34] This idea is also supported by Aykaç [35] who explores the teacher and students' attitudes towards CMC application in support of teaching speaking skills. 
In order that learning by using $\mathrm{CMC}$ become interesting and give an impact on improving the quality of learning, there are three conditions that must be met, namely: (1) Simple: instructions given by the lecturer are easy to follow and the materials provided are easy to understand (2) Personal: interactions of lecturer and students should be built well like the communication happen in front of the class. In addition, the lecturer need to consider the progress of the students and help all the problems they face; (3) Quick: lecturer give fast and quick response to the needs of students.

CMC should be developed due to the principle of conventional teaching, but learning materials are transferred into a digital system via the internet. In the preparation of the materials, the lecturer should remain pay attention to learning elements such as the formulation of learning objectives, apperception or pre-test, motivation, using communicative language, description of clear material, concrete examples, problem solving, discussions, posttest until the assignment and follow-up activities.

\section{Research Method and Procedure}

The design of this research was one group pretest-posttest experimental design [36] and was carried out at English Study Program FKIP - Riau University during odd semester 2015-2016. The population of the research was 102 students who were joining Writing II class, because only this class was offered at the time the research was conducted. Using cluster sampling technique, as many as 30 students (students from class B) were chosen as the sample. The type of CMC used in this research was asynchronous mode, using e-mail in teaching writing. This mode was chosen because all students were quiet familiar with e-mail, as well as practical because the students could read the materials, browsed internet for the project, and did the project not only by using their computers, but also by using their smartphone anywhere and anytime they like. This situation also increased the students' motivation in studying. To make sure that the learning activities would run well, the students were gathered in our computer laboratory and explained to them the learning activities that would join clearly. The students were given the explanation of how the process of learning through CMC would be implemented, how to find learning materials via the internet, how to write and send emails, and etc.

The next step, the students were given several projects to finish based on the learning materials that were already prepared. To complete this project the students need to be connected to the internet and searched necessary information for the completion of a given project. In completing their project, the students could share their opinion with friends via e-mail. The answers then were sent via e-mail to the lecturer, and the e-mail is authentic evidence of learning activities. Later, the lecturer gave comments on the paper of every student also via e-mail. The instrument used to obtain the data about the students' writing ability was a writing test. This test was given as a pre-test and post-test. Then, in order to determine the influence of CMC application on students' writing ability, the data were analyzed statistically by using analysis of Kolmogorov Smirnov, Homogeneity of Variance Test, and Paired Samples Test. Another instrument used was a questionnaire. This questionnaire consisted of two parts. The first part was intended to know about the students' personal information including age, sex, and students' major use of computer. The second part of the questionnaire was intended to obtain the data about students' perceptions on CMC application. For the data collected from the questionnaire, the researcher determined frequencies, percentages and means to the Likert-scale items for each. 


\section{Results and Discussions}

This part presents about influence of CMC application on the students' writing ability as well as their responses to the given questionnaire.

\subsection{The Influence of CMC Application on the Students' Writing Ability}

The first research question is: Is there any significant influence of CMC application on the students' writing ability?

Several steps of analysis were done to answer this question. The first analysis performed was to test the normality of the value of the pretest and posttest. Through analysis of Kolmogorov Smirnov it can be seen that: (1) The Pretest: It appears that at significant column (Asymp. Sig (2-taild) is 0.554 or the probability is bigger than 0.05 . It means that Ho is accepted to have normally distributed population; (2) Posttest: It appears that at significant column (Asymp. Sig (2-taild)) is 0928 or the probability is bigger than 0.05. It means that Ho is accepted to have normally distributed population. Based on the calculation, it can be said that both variables are normally distributed and regression requirements are fulfilled. For more details, see Table 1:

Table 1. Kolmogorov-Smirnov Analysis

\begin{tabular}{llrr}
\hline & & Pretest & Posttest \\
\hline $\mathrm{N}$ & & 30 & 30 \\
Normal Parameters $^{\mathrm{a}}$ & Mean & 66.1333 & 69.8333 \\
& Std. Deviation & 9.30974 & 7.77744 \\
Most Extreme Differences & Absolute & .145 & .100 \\
& Positive & .145 & .100 \\
& Negative & -.096 & -.080 \\
Kolmogorov-Smirnov Z & & .794 & .545 \\
Asymp. Sig. (2-tailed) & & .554 & .928 \\
\hline
\end{tabular}

The next step of analysis was to test homogeneity of variance in order to know whether the data of students' writing ability were homogeneous. The result can be seen on Table 2 .

Table 2. Homogeneity of Variance Test

\begin{tabular}{cccc}
\hline Levene Statistic & df1 & df2 & Sig. \\
1.918 & 9 & 18 & .114 \\
\hline
\end{tabular}

From Table 2 it can be seen that the significant value of posttest variable $(\mathrm{Y})$ based on pretest variable $(\mathrm{X})=0.114>0.05$, meaning that variable data posttest $(\mathrm{Y})$ based on pretest variables $(\mathrm{X})$ has the same variant or homogeneous. The next analysis is to determine the effectiveness of using CMC on students' writing ability, it is necessary to calculate the t-test. The result can be seen on Table 3 . 
Table 3. Paired Samples Test

\begin{tabular}{|c|c|c|c|c|c|c|c|c|}
\hline & & & & Paired Diffe & nces & & & \\
\hline & & & Std. & Std. Error & $\begin{array}{l}95 \% \text { Confide } \\
\text { of the Di }\end{array}$ & $\begin{array}{l}\text { Interval } \\
\text { rence }\end{array}$ & & Sig. (2- \\
\hline & & Mean & Deviation & Mean & Lower & Upper & df & tailed) \\
\hline $\begin{array}{l}\text { Pair } \\
1\end{array}$ & $\begin{array}{l}\text { Pretest - } \\
\text { Posttest }\end{array}$ & $3.70000^{-}$ & 6.35257 & 1.15982 & -6.07209 & -1.32791 & $3.190^{-} 29$ & .003 \\
\hline
\end{tabular}

From the result of $\boldsymbol{t}$ analysis, it is obtained that the value of $\boldsymbol{p}$ is as many as 0.003 . This value is smaller than the significance value $\alpha(0,025)$. It means that there are significant differences between mean score of students' pretest and posttest. It means that the application of the CMC is able to improve students' writing ability.

Based on the analysis above, it can be mentioned that CMC application can improve the students' writing ability. This improvement is due to several things. First, the students say that CMC application gives them special benefits, one of which they can finish their project in a comfortable way because they can interact directly with the lecturer and friends without fear. Secondly, the CMC application provides interaction in group works, peer discussions and corrections, and direct feedback from lecturer. These features can give positive influence on students' attitude and writing performance. This finding supports the idea given by Young in [31] and Hussin, et al. [32].

Next point is that learning with CMC application is able to facilitate the students with new learning atmosphere that may reduce the psychological barriers, and stress when they try to express their ideas in a written form. This situation happen because communicate in internet give them possibilities to have a time delay so that they are able to think better in completing the tasks. In addition, the students may begin their learning activities at the time they are ready to study or to complete their project. They can do the activities anywhere they like.

Finally, CMC application encourages the students to write collaboratively to finish the project as they control their own learning process. Ultimately CMC application improves motivation and interest in studying the aspects they learned. This idea is in line with the opinion of Young in [31] that says that communication via e-mail can increase the motivation and the ability to write.

\subsection{The Students' Perceptions on CMC Application in Writing Class}

The second research question is: How is the students' perceptions on CMC application in writing class?

Based on the response given by the students, it can be informed that the age of the students who joined this research are between 17 to 19, and 7 of them are male and 23 are female. Every student has a computer (lap top). According to data analysis, as many as 93.3\% of the students use computer mainly to search information to complete tasks given by lecturers. $43.3 \%$ of them say that they use computer and internet to play games and music, while $70 \%$ of students use computer and internet use e-mail in their daily activities. It is interesting to note that all of students say that they ever use their computer and internet to create power point for presentation. Perceptions of the students can be seen in the following Table 4. 
Table 4. Students' Perceptions on CMC Application

\begin{tabular}{|c|c|c|c|c|c|c|}
\hline \multirow[t]{2}{*}{ No } & \multirow[t]{2}{*}{ Statements } & \multicolumn{5}{|c|}{ Percentage } \\
\hline & & $1 *$ & $2 *$ & $3 *$ & $4 *$ & $5 *$ \\
\hline 1 & CMC makes me able to practice typing better and faster. & & & 6.6 & 50 & 43.3 \\
\hline 2 & CMC makes me know more about computers. & & & 10 & 46.7 & 43.3 \\
\hline 3 & CMC helps me to improve my ability in using e-mail and online chat. & & & 13.3 & 53.3 & 33.3 \\
\hline 4 & CMC makes me able to learn English better. & & & 20 & 63.3 & 16.7 \\
\hline 5 & $\begin{array}{l}\text { Obtaining relevant and interesting information on the internet makes } \\
\text { me more motivated. }\end{array}$ & & & 16.7 & 46.6 & 36.7 \\
\hline 6 & Learning while communicating via e-mail was fun and enjoyable. & & & 26.7 & 50 & 23.3 \\
\hline 7 & $\begin{array}{l}\text { Searching for information via internet can improve my reading } \\
\text { comprehension as well as increase my vocabulary. }\end{array}$ & & & 23.3 & 40 & 36.7 \\
\hline 8 & $\begin{array}{l}\text { CMC makes me more capable of finding errors and correcting my own } \\
\text { writing }\end{array}$ & & & 10 & 56.7 & 33.3 \\
\hline 9 & $\begin{array}{l}\text { Reading English material directly from the internet cause my } \\
\text { understanding of grammar, particularly about sentence patterns and } \\
\text { grammatical patterns increased. }\end{array}$ & & & 23.3 & 66.7 & 10 \\
\hline 10 & $\begin{array}{l}\text { Direct corrections and assistance provided through e-mail by my } \\
\text { lecturer improved my understanding. }\end{array}$ & & & 10 & 43.3 & 46.7 \\
\hline
\end{tabular}

Note: $* 1=$ strongly disagree $; 2=$ disagree; $3=$ neutral; $4=$ agree; $5=$ strongly agree

The Table 4 above shows that the average score of students who answered agree and strongly agree were as many as 80.7. Most of the students agree that the learning activities with CMC allows them to practice typing better and faster, know more about computers and improve their skills in using e-mail and chatting online. In addition, the students also argue that the CMC allows them to learn English better because they can search for relevant and interesting information, thus increasing motivation, as well as being able to find errors and correct their own writings.

Most of the students also agree that direct reading materials through internet make their understanding about grammar increases, especially about sentence patterns and grammatical patterns. Direct corrections and guidance given by lecturer also improve their understanding. According to the students, learning while communicating via e-mail is fun, enjoyable and can improve reading comprehension as well as increase vocabulary.

\section{Conclusion}

This paper has successfully presented that CMC application has given significant influence on students' writing ability. The results of this study also determine that CMC application in the teaching writing is important because it can help the students to enlarge their sight and knowledge about the use of computer and internet. Moreover, the application of CMC helps them understand the material being taught better. Students' perceptions of CMC application in the learning activities are also good, proved by the students' response on the questionnaire given.

Despite the fact that $\mathrm{CMC}$ application is able to give positive effects toward the students' ability, most of students are not realize the benefit of it yet. Since they are already familiar with using computers and Internet it will be easy for the lecturers to introduce other modes of CMC application like Facebook and blog. Besides, the next researcher may try to use CMC application to improve students' ability in other skills like speaking, reading and listening. 


\section{Acknowledgement}

This work is supported by Dean of Faculty of Teachers Training and Education Research Grant of Universitas Riau no 1873/UN19.5.1.1.5/TU/2015.

\section{References}

[1] http://fkip.unri.ac.id/pendidikan-bahasa-dan-sastra-inggris/ Curriculum 2014. English Study Program, Faculty of Teachers Training and Education Faculty - Riau University.

[2] Santangelo, T. and Olinghouse, N. G. 2009. Effective Writing Instruction for Students Who Have Writing Difficulties. Focus on Exceptional Children 42 (4): 1-20.

[3] Hadriana and Mahdum. 2014. Efektifitas Pembelajaran Berbasis Web Terhadap Writing Skill Mahasiswa Prodi Pendidikan Bahasa Inggris. FKIP Universitas Riau.

[4] Mumtaz, S. (2000). Factors affecting teachers' use of information and communications technology: a review of the literature. Journal of information technology for teacher education, 9(3), 319-342.

[5] Khalid, M. S., Alias, M., Razally, W., Yamin, S., \& Herawan, T. (2010). The effect of using an interactive multimedia courseware within a collaborative learning environment on the learning of prealgebra concepts among pre-university engineering students. Procedia-Social and Behavioral Sciences, $8,571-579$.

[6] Khalid, M. S., Wai, T. L., \& Herawan, T. (2012). Road traffic engineering application in mathematics information technology. Procedia-Social and Behavioral Sciences, 59, 204-211.

[7] Khalid, M. S., Sutoyo, E., Sari, E. N., \& Herawan, T. (2014). Teaching and Learning Using Computers: How Should We Tread on Its' Changing Technology?. International Journal of Emerging Technologies in Learning, 9(5).

[8] Dutt, A., Ismail, M. A., \& Herawan, T. (2017). A Systematic Review on Educational Data Mining. IEEE Access, DOI: 10.1109/ACCESS.2017.2654247.

[9] Green, T. 2005. Using technology to help English language students develop language skills: a home and school connection. Multicultural Education, 13(2): 56-4.

[10] Fano, R. M. (1984, August). Computer mediated communication. In 1984 Technical Symposium East (pp. 34-38). International Society for Optics and Photonics.

[11] Walther, J. B. (1996). Computer-mediated communication: Impersonal, interpersonal, and hyperpersonal interaction. Communication research, 23(1), 3-43.

[12] Simpson, J. (2002). Computer-Mediated Communication. ELT journal, 56(4), 414-15.

[13] Thurlow, C., Lengel, L., \& Tomic, A. (2004). Computer mediated communication. Sage.

[14] Masoni, M., Guelfi, M. R., \& Shtylla, J. (2011). Computer mediated communication. In E-learning in sanità (pp. 17-22). Springer Milan.

[15] Bakardjieva, M. (2016). Computer-Mediated Communication. The International Encyclopedia of Communication Theory and Philosophy.

[16] Berge, Z. L. and M. P. Collins. 1995. Computer Mediated Communication and the Online Classroom:Overview and Perspectives. Cresskill, NJ: Hampton Press, Inc.

[17] Chitravelu, N., Sithamparan S. \& Ten S.C. 2004. ELT Methodology and Practiceion. Selangor.Penerbit Fajar Bakti Sdn. Bhd.

[18] Yahya Othman \& Roselan Baki. 2007. Aplikasi komputer dalam pengajaran bahasa : Penguasaan guru dan kekangan dalam pelaksanaan. 1st International Malaysian Educational Technology Convention: 2-5 November 2007. Hlm. 183-297.

[19] Massi . M. P. 2001. Interactive Writing in the EFL Class: A Repertoire of Tasks. The Internet TESL Journal, 7 article no 6.

[20] Leki, I. 1994. Teaching Second Language Writing. In Lestari, Lies Amin: The Interactional Approach to the Teaching of Writing and Its Implications for Second Language Acquisition. TEFLIN Journal 19 (1): $42-56$.

[21] Ur, P. 2000. A Course in Language Teaching: Practice and Theory. Cambridge. Cambridge University Press.

[22] Brown, D. 2001. Teaching by Principles: An Interactive Approach to Language Pedagogy. 2nd ed. White Plains: Addison Wisley Longman. Inc.

[23] Hughes, A. 2002. Testing for Language Teachers. 2nd edition. Cambride: Cambride University Press.

[24] Graham, S., \& Perin, D. 2007. What we know, what we still need to know: Teaching adolescents to write. Scientific Studies of Reading, 11(4), 313-335.

[25] Peterson-Karlan, G. R., \& Parette, H.P. (2007). Supporting struggling writers using technology: Evidence-based instruction and decision-making. Illinois state University, Department of special Education, special Education Assistive Technology center.

[26] Tomic, C. T. (2004). Computer Mediated Communication Social Interaction and the Internet. London: SAGE.

[27] Hirvela, A. 2006. Computer-mediated communication in ESL teacher education. ELT Journal, 60, 233241. 
[28] Dabbagh, N. \& Bannan-Ritland, B. 2005. Online Learning: Concepts, Strategies, and Application. New Jersey: Pearson Education. Inc.

[29] Lancaster, S., 2007. "The selection of instant messaging or e-mail: College students' perspective for computer communication." Information Management \& Computer Security, Vol. 15, (No. 1), pp. 5-22.

[30] [30]Landry, B. J. L., 2006. "Measuring Student Perceptions of Blackboard Using the Technology Acceptance Model." Decision Sciences Journal of Innovative Education, Vol. 4, (No. 1).

[31] Young. 2003. Integrating ICT into Second Language Education in a Vocational High School. Journal of Computer Assisted Learning. 19(4) : 447-461.

[32] Supyan Hussin. 2015. The Effects of CMC Applications on ESL Writing Anxiety among Postgraduate Students. English Language Teaching 8 (9) 167-172

[33] Noriah, I., \& Intan, S. M. A. A. (2012). An Analysis of ESL Students' Attitude and Interest Towards Learning to Write Essays using Selected Online Writing Links and Resources. The International Journal of Knowledge, Culture and Change Management, 11(6), 187-198.

[34] Abrams, Z. I. 2003. The effect of synchronous and asynchronous CMC on oral performance in German. The Modern Language Journal, 87(2).

[35] Aykaç, M. 2005. Students' and Teachers' Attitudes Towards the Use of Computer-Mediated Communication Voice \& Text Chat as an Instructional Resource to Improve Speaking Skill. A Master's Thesis. Bilkent University Ankara.

[36] Cresswell, J.W. 2008. Educational Research Planning, Conducting and Evaluating Quantitative and Qualitative Research. Edisi ke-3. New York: Pearson Education International. 
International Journal of Multimedia and Ubiquitous Engineering Vol.12, No.4 (2017) 